Article

\title{
The Effect of Shape-Controlled Pt and Pd Nanoparticles on Selective Catalytic Hydrodechlorination of Trichloroethylene
}

\author{
Oğuz Yunus Sarıbıyık ${ }^{1,2,3, * \mathbb{C}}$, Christian Weilach $^{1}$, Selahattin Serin ${ }^{2}$ and \\ Günther Rupprechter $1, *$ (D) \\ 1 Institute of Material Chemistry, TU Wien, A-1060 Vienna, Austria; c.weilach@lenzing.com \\ 2 Department of Inorganic Chemistry, Çukurova University, Adana 01330, Turkey; sserin@cu.edu.tr \\ 3 Department of Genetics \& Bioengineering, Gümüşhane University, Gümüşhane 29100, Turkey \\ * Correspondence: oysaribiyik@gumushane.edu.tr (O.Y.S.); guenther.rupprechter@tuwien.ac.at (G.R.)
}

Received: 16 October 2020; Accepted: 11 November 2020; Published: 13 November 2020

check for updates

\begin{abstract}
Tailoring the shape of nanoscale materials enables obtaining morphology-controlled surfaces exhibiting specific interactions with reactants during catalytic reactions. The specifics of nanoparticle surfaces control the catalytic performance, i.e., activity and selectivity. In this study, shape-controlled Platinum (Pt) and Palladium (Pd) nanoparticles with distinct morphology were produced, i.e., cubes and cuboctahedra for Pt and spheres and polyhedra/multiple-twins for Pd, with (100), $(111+100)$, curved/stepped and (111) facets, respectively. These particles with well-tuned surfaces were subsequently deposited on a Zirconium oxide $\left(\mathrm{ZrO}_{2}\right)$ support. The morphological characteristics of the particles were determined by high resolution transmission electron microscopy (HR-TEM) and X-ray diffraction (XRD), while their adsorption properties were investigated by Fourier transform infrared spectroscopy (FTIR) of CO adsorbed at room temperature. The effect of the nanoparticle shape and surface structure on the catalytic performance in hydrodechlorination (HDCl) of trichloroethylene (TCE) was examined. The results show that nanoparticles with different surface orientations can be employed to affect selectivity, with polyhedral and multiply-twinned $\mathrm{Pd}$ exhibiting the best ethylene selectivity.
\end{abstract}

Keywords: hydrodechlorination; Platin and Palladium nanoparticles; shape control; catalytic selectivity

\section{Introduction}

Chlorine containing organic molecules have been widely used in industry as dry cleaning solvents for degreasing, as intermediates for the production of refrigerants [1,2] or for micro structured silicon carbide films in semiconductor production [3]. However, the contamination by chlorinated organic compounds is very hazardous for the environment and causes pollution of underground water, depletion of the ozone layer and threats the human health because of toxicity and carcinogenic effects [3-10]. Trichloroethylene (TCE), being a chlorinated organic solvent, is a volatile molecule and exposure to TCE causes liver and lung tumor in mice, kidney and cervix cancer, serious central nervous problems and is potentially carcinogen for humans [3,10]. Recycling and recovery are recommended instead of disposal [11-13], because thermal treatments such as incineration or catalytic combustion produce dioxine, chloro-furan and phosgene as byproducts [14-20]. Environmental concerns thus motivate developing an efficient elimination of those chemicals, preferentially by converting them to less harmful or even useful chemicals.

In this respect, catalytic hydrodechlorination $(\mathrm{HDCl})$ is one of the most suitable reactions, involving noble metals such as platinum or palladium converting chlorinated organic compounds 
to fine chemicals [21-29]. The selectivity and stability of the catalysts are the key features and many groups have devoted significant efforts on these topics [30,31]. The structure sensitivity of the reaction has been debated, as there are a variety of influencing effects. The support material [32-35], metal/support interactions [31,36-40], pretreatment and reaction conditions [23,41], metal surface orientation $[29,42-48]$ and metal dispersion/particle size $[33,36,37,44,46,49-53]$ are crucial for efficient selective catalytic reactions. Specifically, the coordination numbers of the metal atoms in the nanoparticles may vary, being, e.g., 9, 8 and 7 in surface planes of (111), (100) and (110), respectively [54-56]. Furthermore, the interaction between the metal surface atoms and the reactants (via adsorption/desorption energies) are critical for selectivity [42,49,57]. However, few reports on $\mathrm{HDCl}$ have focused on the relationship between well-controlled nanoparticle surfaces and their catalytic performance, especially selectivity. The current study of the effect of shape and surface structure of $\mathrm{Pt}$ and $\mathrm{Pd}$ nanoparticles on the $\mathrm{HDCl}$ reaction should thus add new aspects on the selectivity of such reactions.

Using shaped-controlled synthesis, the effects of different surface orientations on catalytic activity/selectivity have been repeatedly examined. Micaela et al. prepared cubes, octahedra and cuboctahedra shaped Pd catalysts and tested their catalytic activity in the selective hydrogenation of 2-methyl-3-butyn-2-ol. Edge atoms were found less active than atoms in planes [58]. The effect of particle size and stepped surfaces of Au nanoparticles on CO oxidation were investigated, showing that the (111) and (100) planes, stepped surfaces and edge atoms exhibit different catalytic properties [55,59-61]. Bimetallic PtRh (111) surfaces possess excellent methanol oxidation activity and resistance towards CO poisoning, while (100) planes were less active and less CO tolerant [62]. The (111) and (100) surface orientation plays an important role also in the selective hydrogenation of unsaturated aldehyde [63]. The adsorption geometry of unsaturated alcohols is very different on $\operatorname{Pt}(111), \operatorname{Pt}(100), \operatorname{Pd}(100)$ and $\operatorname{Pd}(110)$ surfaces [64]. Altogether, such studies shed light on the relationship between surface morphology and reactivity and are clearly relevant for selective catalytic hydrogenation.

The goal of this work was to prepare shape-controlled platinum and palladium nanoparticles (NPs) by a modified synthetic polyol method, finally yielding cubic (c) and cuboctahedral (co) Pt NPs and spherical (s) and mixed shaped (m; polyhedral and multiply-twinned) Pd NPs. The polyol reduction method was chosen for preparation because the involvement of secondary metals, e.g., $\mathrm{Na}$, $\mathrm{Ag}$ or Fe used as reducing agents during other NP synthesis, would change the properties of the NPs [65-67]. To our knowledge, this is the first study of shape-controlled NPs employed for the selective $\mathrm{HDCl}$ reaction.

After the synthesis of the shaped NPs, they were deposited on zirconia [68] and characterized by high resolution transmission electron microscopy (HR-TEM), X-ray diffraction (XRD) and Fourier transform infrared (FTIR) spectroscopy of adsorbed CO at room temperature. To facilitate and improve the quality of HR-TEM and XRD, carbon films and SBA-15 were also used as support, respectively. The effects of particle shape and surface structure on selectivity were tested in the $\mathrm{HDCl}$ reaction of TCE. The catalytic studies showed that the selectivity strongly depended on the type of metal and the shape of the nanoparticles, with polyhedral and multiply-twinned Pd exhibiting the best selectivity.

\section{Results and Discussion}

The growth of shaped-controlled nanoparticles critically depends on the applied synthesis conditions, and the reader is referred to reviews for in-depth accounts $[55,68,69]$. The size, shape, lattice structure and adsorption properties of the Pt and Pd NPs were evaluated by (HR-)TEM, aided by fast Fourier transform (FFT) analysis, XRD and CO-FTIR. 


\subsection{Characterization of NPS by (HR-)TEM}

\subsection{1. (HR-)TEM of Cubic (c) Pt NPs}

The cubic (c) Pt NPs expose six $\{100\}$ surface faces and show well-defined lattice fringes in $<100>$ direction (Figure 1a,b). According to the HR-TEM image in Figure 1c, the distance between the adjacent lattice fringes corresponds to (200) planes of Pt. The corresponding diffraction pattern in the Fast Fourier Transform (FFT) of the selected particle confirms the lattice spacing (Figure 1d), in agreement with previous studies [18,70-73]. The mean size of the cubic Pt NPs was $7.8 \mathrm{~nm}$, based on the analysis of 120 individual particles.

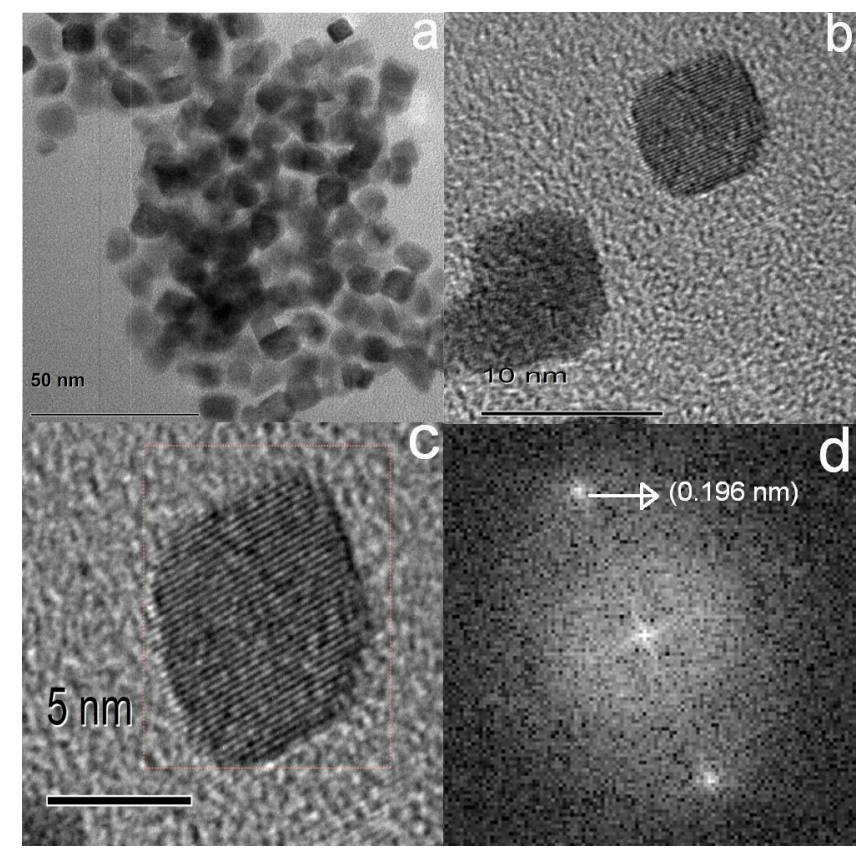

Figure 1. (HR-)TEM micrographs of cubic (c) Pt NPs: (a) overview; (b,c) HR-TEM; and (d) FFT pattern.

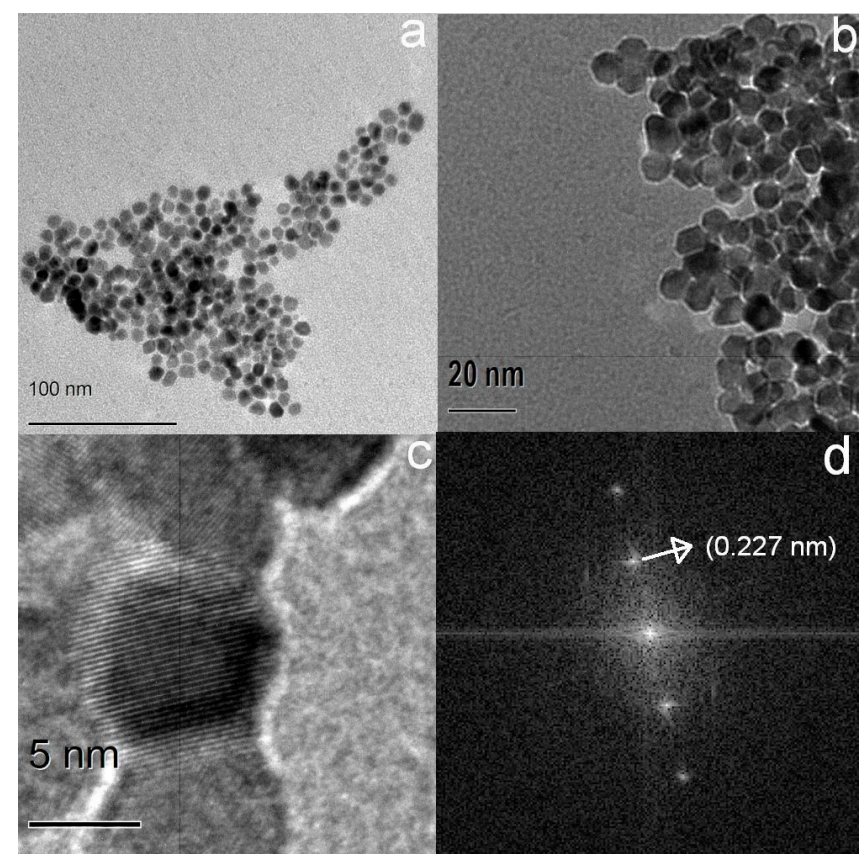

Figure 2. (HR)TEM micrographs of cuboctahedral (co) Pt NPs: (a,b) overview; (c) HR-TEM; and (d) FFT pattern. 


\subsection{2. (HR-)TEM of Cuboctahedral (co) Pt NPs}

The cuboctahedral (co) Pt NPs are displayed in Figure 2a-c at different magnifications, with about $90 \%$ of the particles exhibiting regular shapes. The co NP in the high-resolution image in Figure $2 \mathrm{c}$ shows typical $\{111\}$ lattice planes, with the FFT confirming the $0.23-\mathrm{nm}$ spacing (Figure 2d) $[46,70,74]$. The size distribution, based on counting more than 120 particles, reveals an average particle size of about $5.7 \mathrm{~nm}$.

\subsection{3. (HR-)TEM of Spherical (s) Pd NPs}

These Pd particles exhibited a spherical shape (Figure 3a-c), without flat facets or defined edges/corners. Therefore, the particles have a curved surface, i.e., an open structure with low coordination sites. The FFT pattern of the selected particles revealed diffraction spots indicating 0.23-nm spacings of (111) lattices (Figure 1d). The different sets are due to the superimposed patterns of three particles. A size distribution plot was constructed by counting about 120 individual NPs in TEM images of the s Pd NPs, yielding an average particle size of $6.5 \mathrm{~nm}$ [75].

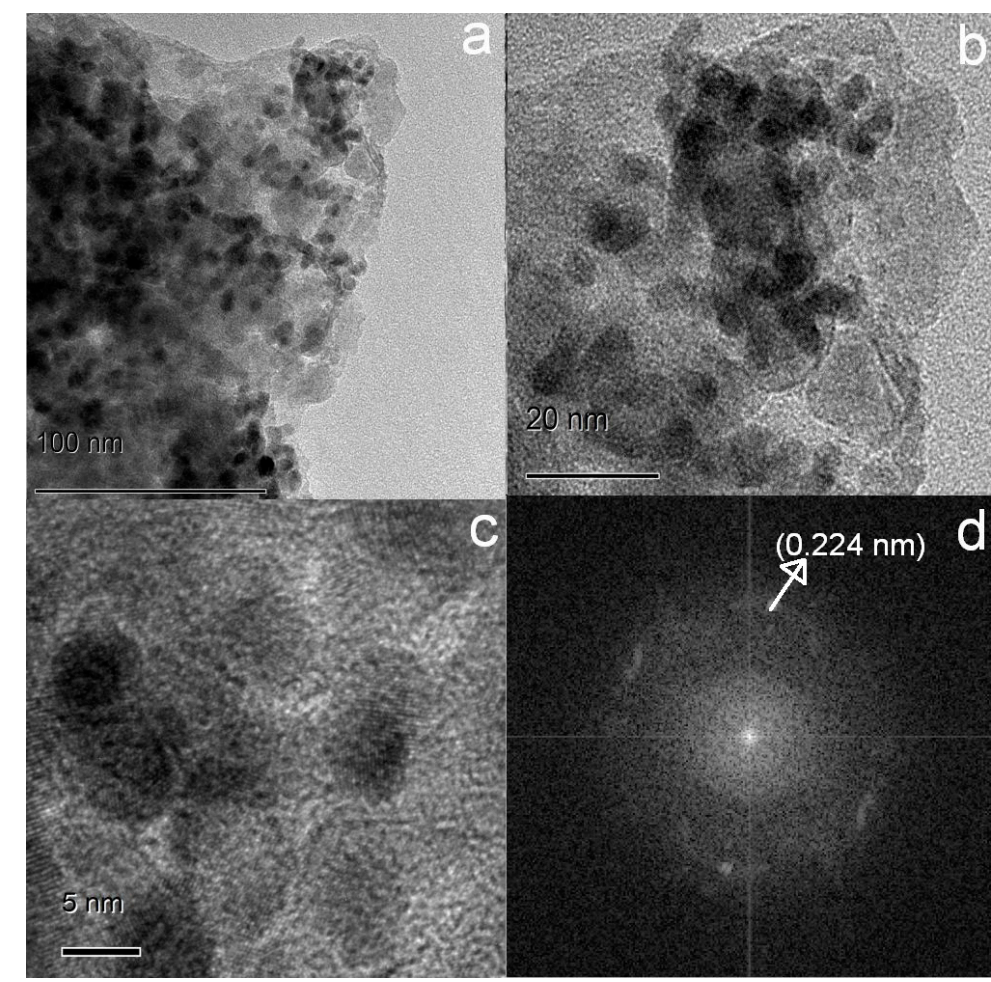

Figure 3. (HR)TEM micrographs of spherical (s) Pd NPs: (a,b) overview; (c) HR-TEM; and (d) FFT pattern.

\subsection{4. (HR-)TEM of Mixed-Shape (m) Pd NPs}

These Pd NPs were of mixed shape, as shown in Figure 4a,b, with multiply-twinned particles in addition to tetrahedral, rhombic and octahedral particles, all of which mostly exhibit $\{111\}$ surfaces. The particles have sharp edges indicating smooth surfaces. A HR-TEM image of a multiply-twinned decahedron is shown in Figure 4c [76]. The interplanar lattice distance of $0.23 \mathrm{~nm}$ is characteristic of (111) planes, and the multiply-twinned structure is confirmed by the FFT pattern (Figure 4d) [77]. According to the size distribution, the mean particles size is $10.1 \mathrm{~nm}$ (counting 120 individual NPs).

The size distribution histograms of cubic and cuboctahedral Pt nanoparticles, and of spherical and mixed-shape Pd nanoparticles, are displayed in Figure 5. The average size ranges from $\sim 5.5$ to $10 \mathrm{~nm}$. 


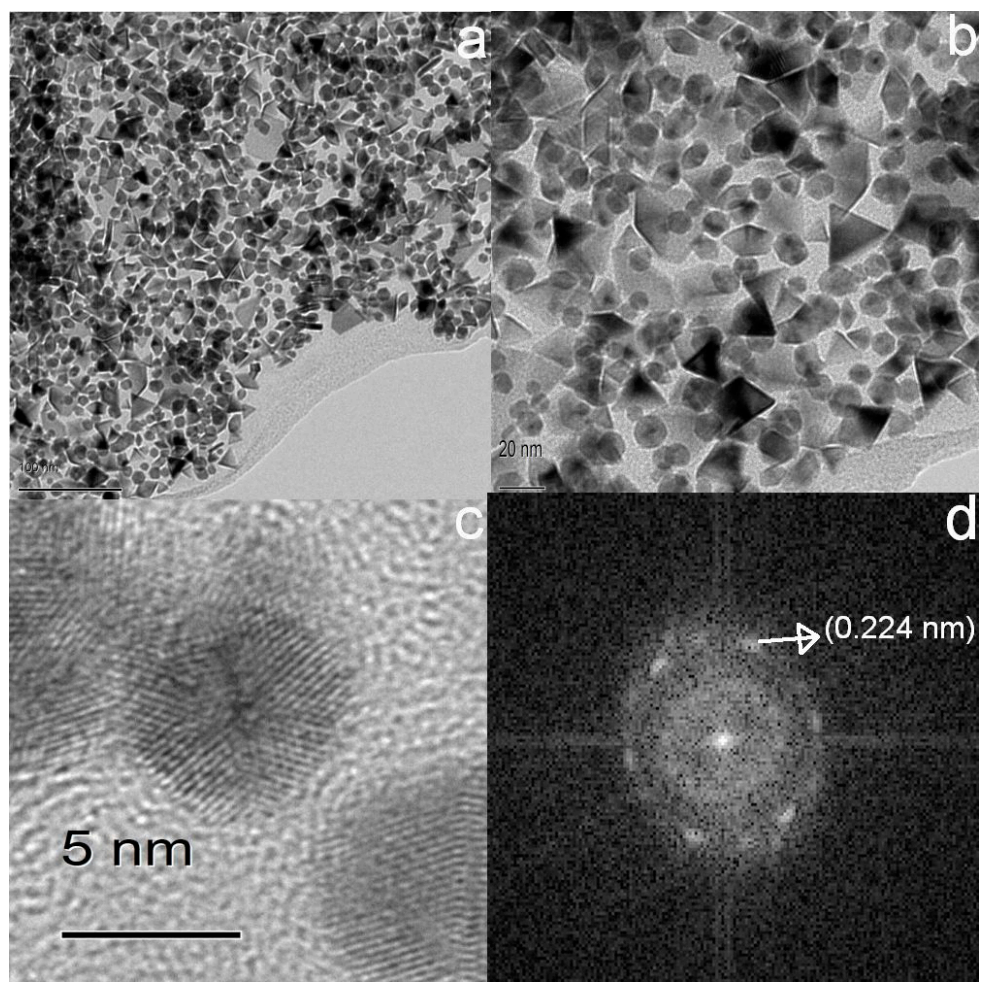

Figure 4. (HR)TEM micrographs of polyhedral and multiply-twinned (mixed shaped m) Pd NPs: overview $(\mathbf{a}, \mathbf{b})$; HR-TEM (c); and FFT pattern $(\mathbf{d})$.

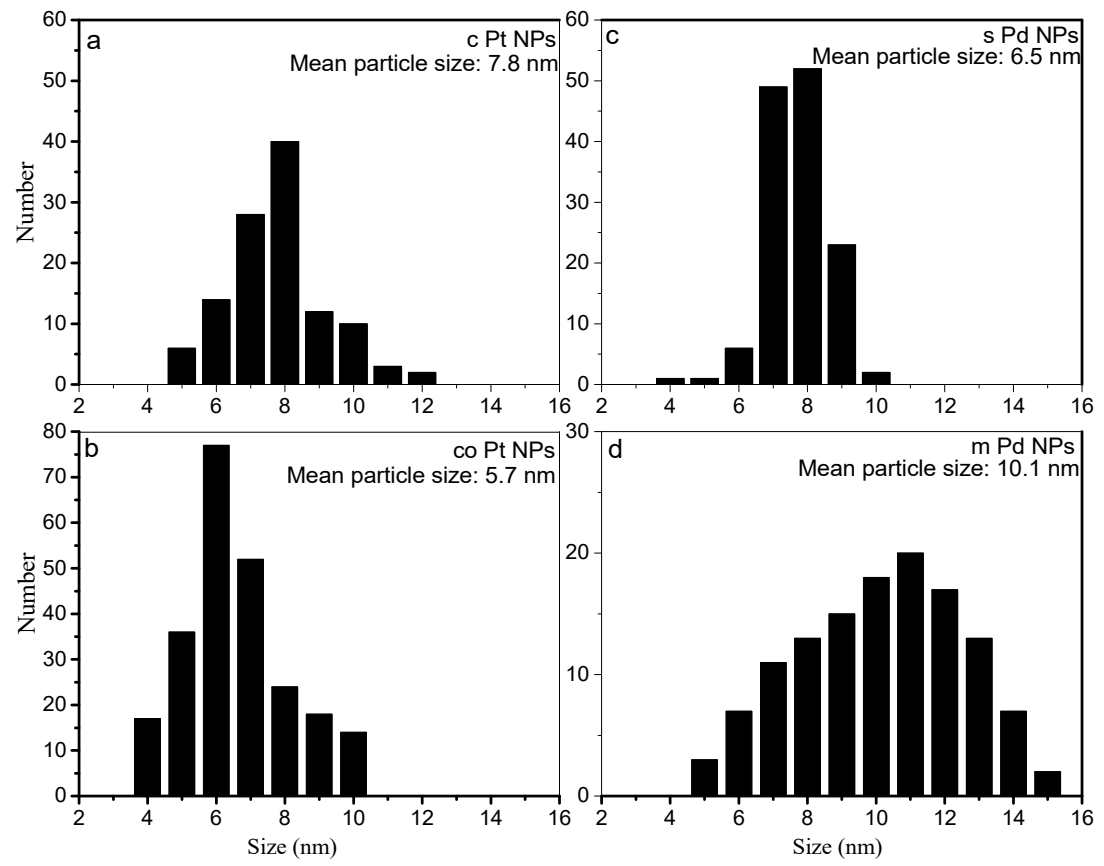

Figure 5. Size distribution histograms of cubic $\mathrm{Pt}(\mathbf{a})$, cuboctahedral $\mathrm{Pt}(\mathbf{b})$, spherical $\mathrm{Pd}(\mathbf{c})$ and mixed-shape Pd (d) nanoparticles (based on counting about 120 particles of each sample).

\subsection{X-ray Diffraction (XRD) of the NPS}

X-ray diffraction was used to confirm the face centered cubic ( $f c c)$ crystal structure of the particles (Figure 6). The XRD patterns of the prepared NPs exhibit the characteristic features of Pt and Pd nanocrystals. As the diffraction peaks of $\mathrm{ZrO}_{2}$ would overlap with those of the metal NPs, we used SBA-15 as support in the XRD analysis (SBA-15 peak at 22 ${ }^{\circ}$ degrees; not shown) [78]. The co Pt NPs 
exhibit two strong reflections at $39.43^{\circ}$ and $46.23^{\circ}$, corresponding to (111) and (200) planes of Pt $[79,80]$. For the c Pt NPs, only a weak (200) peak occurred, reflecting the texture of the cubic particles. In this respect, the XRD data and the TEM results are consistent [74,79-81]. The XRD of spherically shaped Pd NPs showed multiple peaks corresponding to (111), (200), (220) and (311), whereas, for the m Pd NPs, only a (111) reflection was observed. The average crystallite size was calculated by the Debye-Scherrer formula, but the average size was smaller than that observed by (HR-)TEM and is not reported here (as size distributions were obtained by TEM) $[82,83]$. This may be due to the inaccuracy of using Debye-Scherrer for small nanoparticles and/or the twinning.
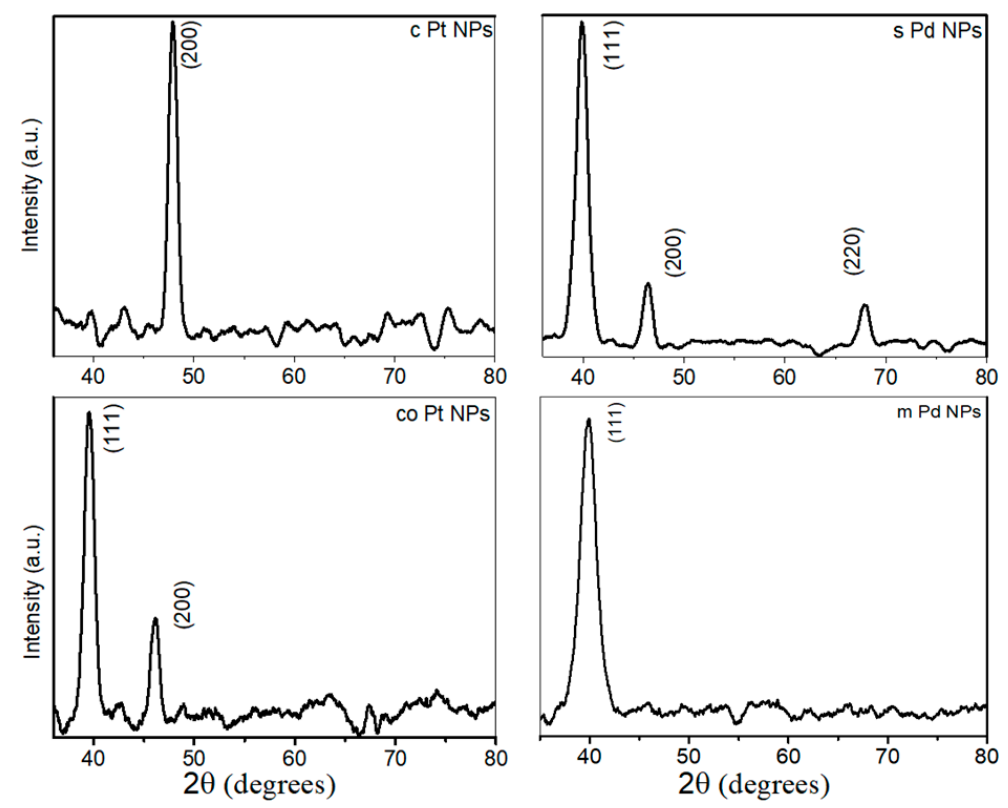

Figure 6. The XRD Patterns of the NPs (supported on SBA-15).

\subsection{Surface Properties of the NPs Examined by FTIR of CO Adsorption at Room Temperature}

The surface adsorption sites present on the NPs were examined by infrared spectroscopy using $\mathrm{CO}$ as probe molecule [84-93]. All FTIR data were acquired after pretreatment (described in the Section 3), in order to remove organic synthesis residues from the particle surfaces (which did not change the NP shapes; see the Supplementary Materials). Then, the NPs were exposed to $10 \mathrm{mbar}$ $\mathrm{CO}$ at room temperature and after evacuation, FTIR spectra were acquired (Figure 7). The stretching vibration of $\mathrm{CO}$ adsorbed on the surface of the NPs indicates the available surface sites, which play a key role in determining the structure sensitivity in the catalytic experiments below. In this respect, it should be noted that $\mathrm{CO}$ can bind to the metal surface atoms in atop, bridge and hollow geometry, the relative abundance of which depends on the specific surface structures ((111), (100), steps and edges) (for detailed descriptions, see [86,90]).

For cubic (c) Pt NPs with (100) facets, the CO adsorption detected at $2049 \mathrm{~cm}^{-1}$ indicates linearly adsorbed (on-top) CO, typical of Pt surfaces [84,85]. On the cuboctahedral particles with (100) and additional (111) facets, again on-top $\left(2051 \mathrm{~cm}^{-1}\right)$, but also bridge $\left(1829 \mathrm{~cm}^{-1}\right)$ bonded CO were observed [94,95]. This difference reflects the different surfaces of $\mathrm{c}$ and co Pt particles.

The stretching frequency of CO adsorption on spherical (s) Pd NPs with curved surfaces, detected at $1911 \mathrm{~cm}^{-1}$, is characteristic of bridge bonded CO on various Pd surfaces. On the mixed shaped Pd NPs with mostly (111) facets, the observed CO band at $1874 \mathrm{~cm}^{-1}$ rather indicates hollow-bonded CO, typical of (111) facets of the $\mathrm{m}$ Pd particles. The peak shift of $37 \mathrm{~cm}^{-1}$ between $\mathrm{s}$ and $\mathrm{m}$ Pd NPs is a clear indication of the difference between curved and (111) Pd surface facets [34]. 

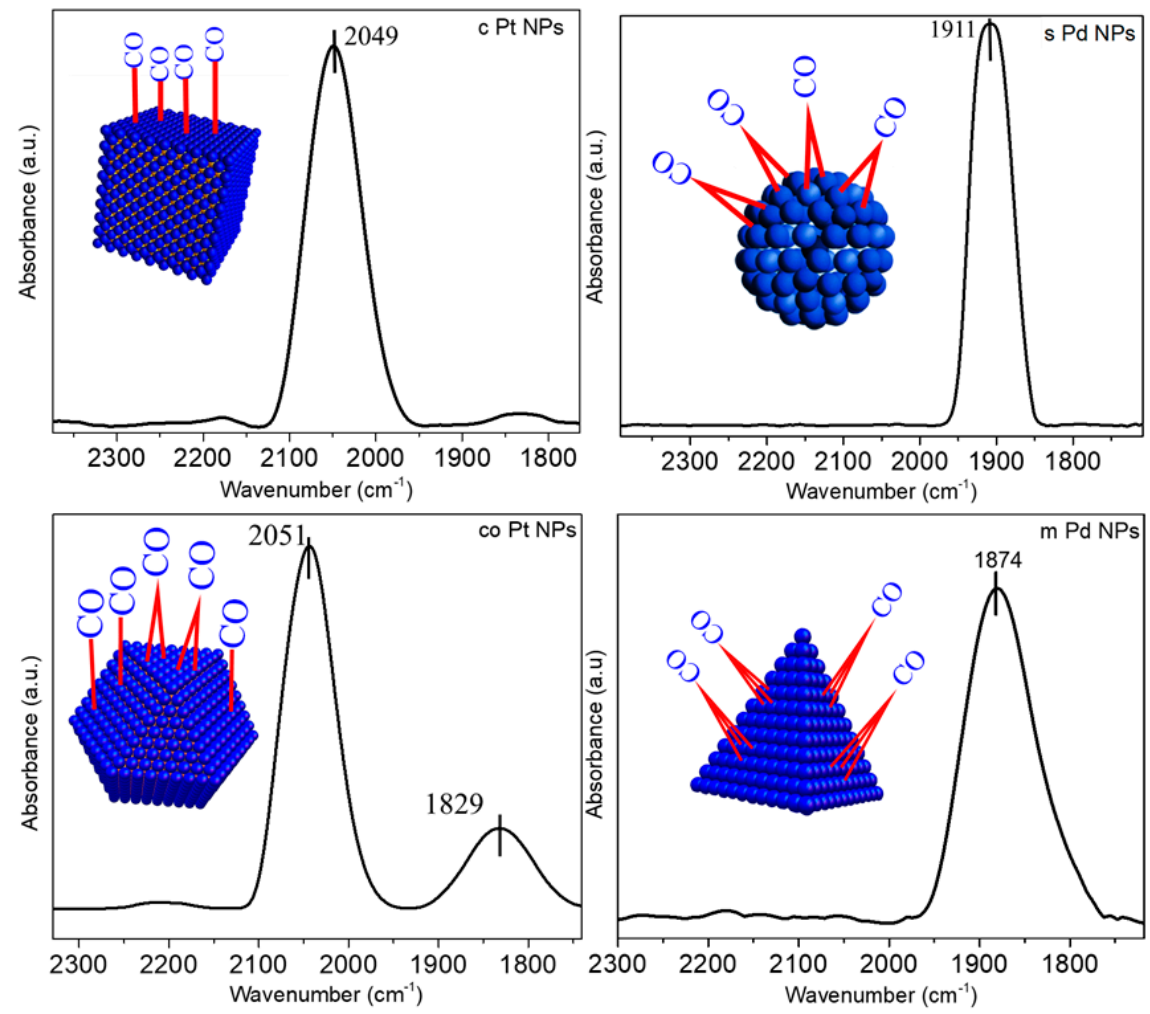

Figure 7. FTIR spectra of Pt and Pd NPs supported on $\mathrm{ZrO}_{2}$, exposed to $10 \mathrm{mbar} \mathrm{CO}$ at room temperature; spectra acquired after evacuation. Adsorbate species are schematically illustrated.

The relationship between the $\mathrm{CO}$ frequency and surface morphology results from low coordinated surface atoms preferring the $5 \sigma\left(\right.$ metal $\left.^{-} \mathrm{d}_{\mathrm{z}}{ }^{2}\right)$ orbital, whereas high coordinated surface atoms favor $2 \pi^{*}\left(\right.$ metal- $\left.\mathrm{d}_{\mathrm{xy}} / \mathrm{d}_{\mathrm{yz}} / \mathrm{d}_{\mathrm{xz}} / \mathrm{d}_{\mathrm{x}}{ }^{2} \mathrm{y}^{2}\right)$ orbitals during electron back donation from the metal surface atom to $\mathrm{CO}$ [96-98]. Therefore, the amount of back donation increases for high coordination and the stretching frequency of CO shifts to lower frequency [97-99]. In turn, low coordinated atoms contribute less back donation yielding higher $\mathrm{CO}$ frequency. In other words, the amount of electron back donation from the metal to CO is larger at a smooth (111) or (100) surfaces than on curved/stepped surfaces.

\subsection{Catalytic Application of Pt and Pd NPs for TCE Hydrodechlorination}

The catalytic performance of the $\mathrm{ZrO}_{2}$ supported Pt and Pd NPs was tested by means of the gas-phase $\mathrm{HDCl}$ reaction of TCE, as illustrated in Figure 8 [22-24,27-29]. Although the different samples did not have a narrow (single) particle size (Figure 5), due to the well-defined shapes, they are still useful to examine shape effects (even the m sample is mostly $\{111\}$ terminated). The exact metal loading was determined by inductively coupled plasma optical emission spectroscopy (ICP-OES) (see Table S1). Before the catalytic tests, all catalysts were washed with acetonitrile five times [79] and pretreated by thermal decomposition of the polyvinylpyrrolidone (PVP) to obtain clean catalyst surfaces. The pretreatment was applied in three steps, following a previous study [100]: (i) oxidation with $50 \mathrm{~mL} / \mathrm{min} \mathrm{O}_{2}$ for $30 \mathrm{~min}$ at $300{ }^{\circ} \mathrm{C}$; (ii) $\mathrm{N}_{2}$ flow at $50 \mathrm{~mL} / \mathrm{min}$ at $300{ }^{\circ} \mathrm{C}$ for $10 \mathrm{~min}$; and (iii) reduction with $50 \mathrm{~mL} / \mathrm{min} \mathrm{H}_{2}$ for $30 \mathrm{~min}$ at $300{ }^{\circ} \mathrm{C}$. The pretreatment and catalytic studies did not change the shape of the NPs (see the Supplementary Materials). The two different series, yield vs. temperature and time vs. yield, were carried out with fresh pretreated catalysts.

Figure 9 compares the $\mathrm{HDCl}$ reaction of TCE on cubic and cuboctahedral Pt NPs supported on $\mathrm{ZrO}_{2}$. On Pt, full hydrogenation to ethane occurred, i.e., no ethylene was detected. Figure 9a shows the temperature dependence of the ethane yield for $\mathrm{c}$ and co Pt NPs. The highest yield was obtained at $150^{\circ} \mathrm{C}$. The yield was low at lower reaction temperature and the catalysts were rapidly poisoned 
at higher temperature than $150{ }^{\circ} \mathrm{C}$. Thus, a reaction temperature of $150{ }^{\circ} \mathrm{C}$ was selected for time dependent study in Figure 9b. A fresh batch of pretreated catalyst was used, with gas phase analysis performed in 22-min intervals. In this case, the ethane yield was higher for co Pt NPs, but for both shapes the yield decreased with time due to deactivation. Nevertheless, no selectivity to ethylene was observed.

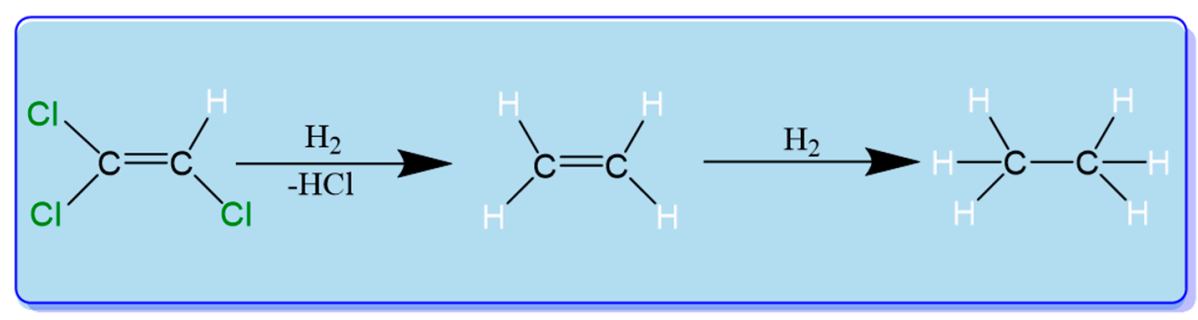

Figure 8. Selective hydrodechlorination (HDCl) of TCE to ethylene. Full hydrogenation to ethane should be avoided.
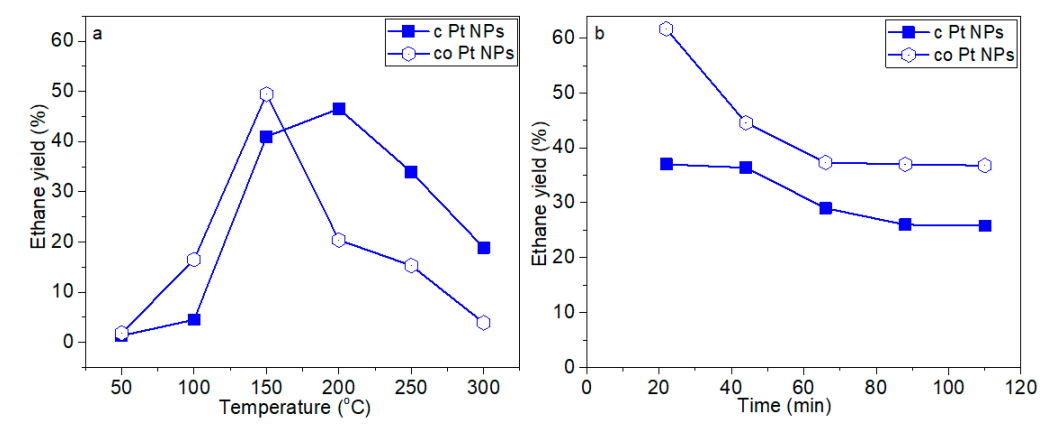

Figure 9. Catalytic $\mathrm{HDCl}$ of TCE on $\mathrm{ZrO}_{2}$ supported cubic (c) and cuboctahedral (co) Pt NPs: (a) ethane yield vs. temperature; and (b) ethane yield vs. time at $150{ }^{\circ} \mathrm{C}$.

The close packed (111) and (100) planes interact with the $C=C$ of TCE via di- $\sigma$ (involving two metal atoms) and/or $\pi$ (involving one metal atom) interaction (Figure 10), resulting in $\mathrm{C}-\mathrm{Cl}$ bond cleavage, as well as the subsequent full hydrogenation of ethylene to ethane $[31,95,99,101-109]$. The catalytic performance of co Pt NPs strongly decreased above $150{ }^{\circ} \mathrm{C}$ (more than c Pt NPs), which may be related to the (111) planes favoring the inactive spectator species ethylidyne (Figure 10). The $\mathrm{c} \mathrm{Pt}$ NPs with only (100) planes deactivated at somewhat higher temperature (Figure 9a) $[108,110,111]$. TCE hydrodechlorination with up to $85 \%$ ethylene selectivity was reported for $\mathrm{Pt} / \mathrm{CeO}_{2}$ catalysts [22,24]. However, a Cl-containing $\mathrm{Pt}$ precursor and a specific synthesis and pretreatment method were crucial to produce the selective $\mathrm{CeOCl}$ species on the support, as well as $\mathrm{Cl}$-poisoned Pt particles limiting full hydrogenation of ethylene. Bimetallic PtCu NPs were reported to have $>90 \%$ ethylene selectivity [22].

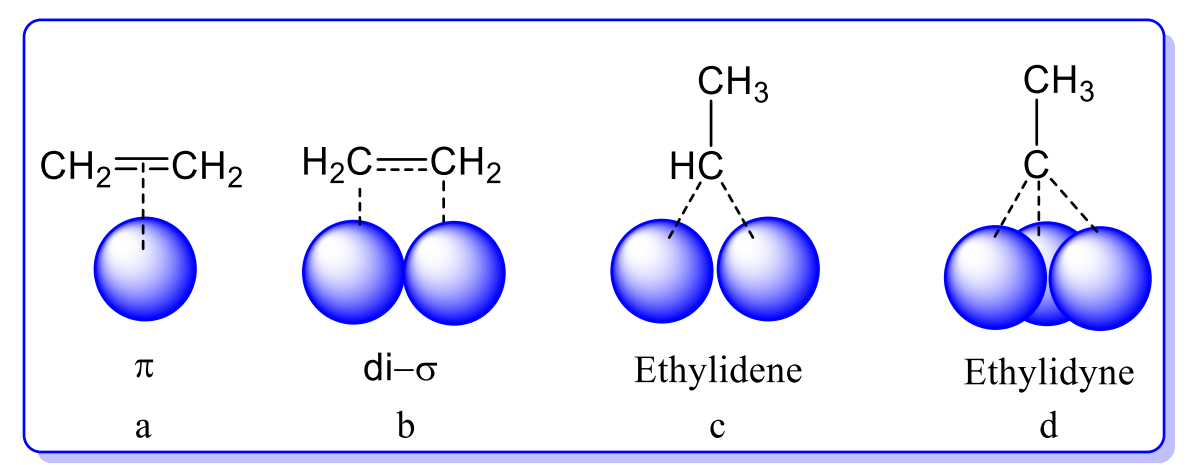

Figure 10. The interaction of ethylene with metal surface atoms. 
The s Pd NPs produced both ethylene and ethane, but ethane still dominated (Figure 11). Figure 11a again shows the temperature dependence, while Figure $11 \mathrm{~b}$ the time dependence. In contrast, the $\mathrm{m} \mathrm{Pd}$ NPs produced more ethylene than ethane, i.e., only the polyhedral and multiply-twinned Pd particles approached the desired selectivity (Figure 12). The deactivation of the Pd NPs, induced by the chlorine poisoning of the surfaces, was beneficial for the selectivity (Figures 11a and 12a), but this was more pronounced for the curved (stepped) s Pd NPs [7,10,21,25,110,112-116].
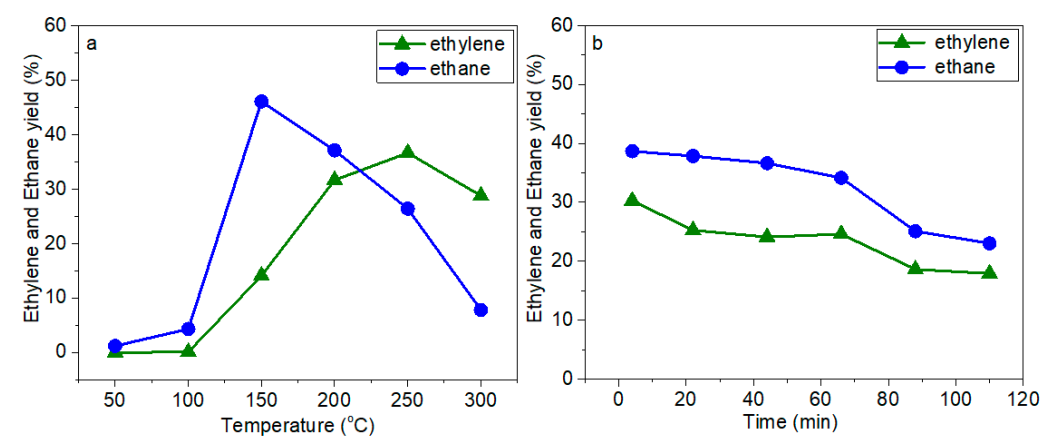

Figure 11. Catalytic $\mathrm{HDCl}$ of TCE on $\mathrm{ZrO}_{2}$ supported spherical (s) Pd NPs: (a) ethylene and ethane yield vs. temperature; and (b) ethylene and ethane yield vs. time at $200{ }^{\circ} \mathrm{C}$.
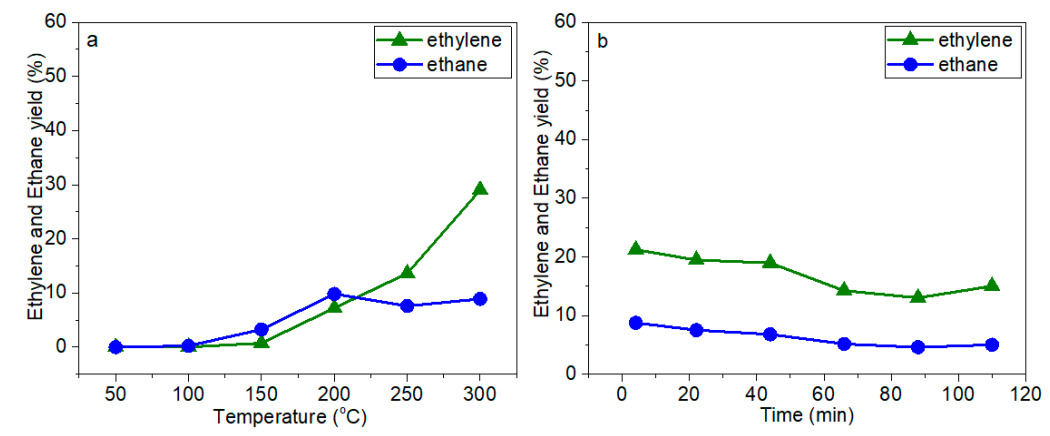

Figure 12. Catalytic $\mathrm{HDCl}$ of TCE on $\mathrm{ZrO}_{2}$ supported mixed-shape (m) Pd NPs: (a) ethylene and ethane yield vs. temperature; and (b) ethylene and ethane yield vs. time at $200{ }^{\circ} \mathrm{C}$.

The stepped surface structures prefer the $\pi$ adsorption mode, while smooth (111) planes of $m$ Pd NPs favor the di- $\sigma$ adsorption mode (Figure 10) $[95,101,104,106,109,110,112,117,118]$. Accordingly, the s Pd NPs may be more prone to produce ethane. However, the stepped surface is already deactivated at $150{ }^{\circ} \mathrm{C}$, likely by $\mathrm{Cl}$ and by carbonaceous species (Figure 11), whereas on the flat surface ethylene increases up to $300^{\circ} \mathrm{C}$ (Figure 12).

In addition, regeneration tests were carried out with the catalysts previously used for the temperature series $\left(50-300{ }^{\circ} \mathrm{C}\right)$. However, they were strongly deactivated and could not be regenerated with the typical pretreatment (at $300{ }^{\circ} \mathrm{C} \mathrm{O}_{2} 30 \mathrm{~min} / \mathrm{N}_{2} 10 \mathrm{~min} / \mathrm{H}_{2} 30 \mathrm{~min}$ ). Higher pretreatment temperatures would likely change the surface and shape of the NPs and were thus not applied. Accordingly, a reaction temperature of $200{ }^{\circ} \mathrm{C}$ should not be exceeded $[14,112,119]$.

Clearly, in situ FTIR during reaction would be preferable [120-123], but this is difficult due to the low coverage and flat orientation of $\pi$-bonded species around $200{ }^{\circ} \mathrm{C}$. More extended studies would be beneficial, but the results of the current catalytic investigations already provided some insight into TCE hydrodechlorination, i.e., how to control selectivity towards ethylene or ethane by shape-controlled synthesis. Pt NPs (c and co) lead to full hydrogenation, Pd NPs (s and m) create both ethylene and ethane, but with a higher ethylene selectivity of polyhedral and multiply-twinned $\mathrm{Pd}$ NPs exposing mostly (111) planes. The rough/stepped Pd surfaces show higher catalytic activity at low temperature, but lower ethylene selectivity. On the other hand, $\mathrm{m}$ Pd NPs exhibit ethylene selectivity which increases at higher temperature and is stable during longer studies up to $400 \mathrm{~min}$. Based on these 
concepts, further optimization towards high selectivity and stability is possible, e.g., by using different precursors, bimetallics, pretreatments and/or intended (stronger) Cl-poisoning of $\mathrm{Pt}$ to prevent full hydrogenation, as reported in [22].

\section{Materials and Methods}

\subsection{Materials}

$\mathrm{PtCl}_{4}$ (>99.99\%), $\mathrm{PdCl}_{2}$ (>99.95\%), polyvinylpyrrolidone (PVP) $\left(\mathrm{M}_{\mathrm{W}} 55000\right)$, triethylene glycol (TEG) (99\%), acetone and acetonitrile were obtained from Sigma Aldrich (Vienna, Austria) and used without any further purification. $\mathrm{ZrO}_{2}$, used as a support material, was produced from $\mathrm{Zr}(\mathrm{OH})_{4}$ which was heated by ramping up the temperature at a rate of $2{ }^{\circ} \mathrm{C} / \mathrm{min}$ to $700{ }^{\circ} \mathrm{C}$ for $2 \mathrm{~h}$ under air flow, followed by cooling down to room temperature. For catalyst cleaning/pretreatment, see Section 3.4.

\subsection{Synthesis of the NPs}

\subsubsection{Synthesis of Cubic (c) Pt NPs and Deposition on $\mathrm{ZrO}_{2}$}

A method, similar to the one reported by Somorjai et al., was used for the production of well-shaped cubic nanoparticles [48]. Briefly, $14.8 \mathrm{mmol}^{\circ} \mathrm{PtCl}_{4}$ and $0.14 \mathrm{mmol}$ of PVP were dissolved in $15 \mathrm{~mL}$ of TEG in a double neck round bottom flask and the reaction was carried out under Ar atmosphere at $200{ }^{\circ} \mathrm{C}$ for $2 \mathrm{~h}$. To deposit the Pt NPs on $\mathrm{ZrO}_{2}$ to nominally obtain $1 \% \mathrm{Pt} / \mathrm{ZrO}_{2}, 10 \mathrm{~mL}$ colloidal solution of Pt NPs were impregnated on $220 \mathrm{mg} \mathrm{ZrO}$ in $10 \mathrm{~mL}$ of acetone and mixed for $2 \mathrm{~h}$ at $50^{\circ} \mathrm{C}$ by using a magnetic stirrer. After the solids settled, the liquid phase was decanted to remove TEG from the solvent and from the surface of the NPs. This step was repeated four times. Finally, the obtained powder was dried in an oven at $100{ }^{\circ} \mathrm{C}$ for $2 \mathrm{~h}$. The exact metal loading was determined by ICP-OES (see Table S1).

\subsubsection{Synthesis of Cuboctahedral (co) Pt NPs and Deposition on $\mathrm{ZrO}_{2}$}

First, $406 \mathrm{mmol}$ of PVP $55 \mathrm{k}$ were dissolved in $15 \mathrm{~mL}$ TEG. After addition of $40.6 \mathrm{mmol} \mathrm{PtCl}_{4}$, the reaction mixture was stirred under argon atmosphere by means of Schlenk line at $230{ }^{\circ} \mathrm{C}$ for $2 \mathrm{~h}$. After the reaction was completed, the same protocol as above was applied for deposition of NPs on Zirconia. The exact metal loading was determined by ICP-OES (see Table S1).

\subsubsection{Synthesis of Spherical (s) Pd NPs and Deposition on $\mathrm{ZrO}_{2}$}

First, $6.68 \times 10^{-2} \mathrm{mmol}$ of $\mathrm{PdCl}_{2}$ and $67.6 \times 10^{-2} \mathrm{mmol}$ of PVP $\left(\mathrm{M}_{\mathrm{W}} 55000\right)$ were dissolved and stirred in a three-neck round bottom flask in $20 \mathrm{~mL}$ of tri-ethylene glycol (TEG) at $220{ }^{\circ} \mathrm{C}$ for $3 \mathrm{~h}$. Afterwards, the reaction was carried out under $\mathrm{N}_{2}$ atmosphere. After the reaction was completed, the same deposition protocol as above was applied for deposition of NPs on zirconia. The exact metal loading was determined by ICP-OES (see Table S1).

\subsubsection{Synthesis of the Mixed-Shaped (m) Pd NPs and Deposition on $\mathrm{ZrO}_{2}$}

First, $0.267 \mathrm{mmol}$ of $\mathrm{PdCl}_{2}$ and $0.16 \mathrm{mmol}$ of PVP $\left(\mathrm{M}_{\mathrm{W}}\right.$ 55000) were dissolved in a three-neck round bottom flask in $20 \mathrm{~mL}$ of triethylene glycol (TEG) and the reaction was carried out under $\mathrm{Ar}$ atmosphere at $160^{\circ} \mathrm{C}$ for $1 \mathrm{~h}$. After the reaction was completed, the same protocol as above was applied for deposition of NPs on zirconia. The exact metal loading was determined by ICP-OES (see Table S1). 


\subsection{Characterization}

3.3.1. Inductively Coupled Plasma Optical Emission Spectrometry (ICP-OES) Analysis of the Pt and Pd NPs

A Perkin-Elmer Optima 2100 DV ICP-OES instrument (Vienna, Austria) was used for the elemental analysis of the supported Pt and Pd catalysts (see Table S1).

\subsubsection{High-Resolution Transmission Electron Microscopy (HR-TEM)}

The microstructure, size, shape and lattice fringes of the Pt and Pd NPs were analyzed in detail by different high resolution and scanning transmission electron microscopes, i.e., a $200 \mathrm{kV}$ FEI TECNAI F20 S-TWIN and FEI Talos F200 STEM (Hillsboro, OR, USA). Solid catalyst samples were directly put onto the copper TEM grid, colloidal liquid samples were loaded as smalls drops onto carbon coated copper TEM grids. Residual PVPs were removed by plasma treatment before analysis.

\subsubsection{X-ray Diffraction (XRD)}

A Bruker D8, discover XRD X-ray diffractometer (Bruker, Vienna, Austria) was used for XRD analysis. XRD measurements of samples were carried out using $\mathrm{Cu} \mathrm{K} \alpha$ radiation $(0.15406 \mathrm{~nm})$ at room temperature [124].

\subsubsection{Fourier Transform Infrared Spectroscopy (FTIR)}

Fourier Transform Infrared (FTIR) spectroscopy experiments were performed at room temperature in the range of 1000 to $4000 \mathrm{~cm}^{-1}$. However, the characteristic features of $\mathrm{CO}$ adsorbed on metal NPs appear in the range of 1800 to $2300 \mathrm{~cm}^{-1}$, which is why only this range is shown. The IR data were acquired in transmission mode with the samples pressed to self-supporting pellets. An average spectrum was obtained by 256 individual scans with a resolution of $2 \mathrm{~cm}^{-1}$, which was repeated 5 times. The IR cell, designed for in situ pretreatment at high vacuum $\left(<10^{-6} \mathrm{mbar}\right)$, was equipped with a ring-shaped furnace and a type $\mathrm{K}$ thermocouple inserted into the sample holder. Gases $\left(\mathrm{CO}, \mathrm{H}_{2}\right.$ and $\mathrm{O}_{2}$ ) were introduced via a leak valve connected from gas lines to the vacuum chamber. All samples were pretreated for cleaning the surfaces of the nanoparticles before the FTIR acquisition. Additional pretreatment procedures were applied to get rid of residual PVPs and solvents. IR spectra were acquired after the following pretreatment processes. As a first step, to remove the surface moisture, a pellet was heated up to $300^{\circ} \mathrm{C}$ at a rate of $10^{\circ} \mathrm{C} / \mathrm{min}$ under vacuum $\left(<10^{-6} \mathrm{mbar}\right)$ and then an oxidation step was applied: 10 mbar oxygen was dosed for $30 \mathrm{~min}$ to the chamber to achieve the oxidation of the organic residues on the surface of the NPs. Finally, for reduction, $10 \mathrm{mbar}$ hydrogen was applied for $30 \mathrm{~min}$. Then, the sample was cooled to room temperature in vacuum. After pretreatment, the CO adsorption (10 mbar) was carried out at room temperature, the cell then evacuated and FTIR spectra acquired.

\subsection{Catalytic HDCl Reaction of TCE}

For the catalytic reactions, a catalyst amount equivalent to $0.5 \mathrm{mg} \mathrm{Pt}$ or Pd was used for each test (as the actual loadings varied between $0.65 \mathrm{wt} . \%$ and $1.48 \mathrm{wt} . \%$ Table S1). The catalytic tests for the $\mathrm{HDCl}$ reaction of TCE were carried out by using a continuous fixed bed vertical flow reactor, equipped with a controlled heating system, in the range of $50-700{ }^{\circ} \mathrm{C}$. Glass tube reactors were placed in a vertical tubular furnace and quartz wool plugs were used to hold the catalyst. Before the catalytic tests all catalysts were pretreated at $300{ }^{\circ} \mathrm{C}$, for $30 \mathrm{~min}$ with $\mathrm{O}_{2}$ at $15 \mathrm{~mL} / \mathrm{min}$, for $10 \mathrm{~min}$ with $\mathrm{N}_{2}$ at $50 \mathrm{~mL} / \mathrm{min}$, followed for $30 \mathrm{~min}$ by $\mathrm{H}_{2}$ at $15 \mathrm{~mL} / \mathrm{min}$. For reaction, helium (as an inert gas) and hydrogen (as reducing agent), supplied via mass flow controllers at $36 \mathrm{~mL} / \mathrm{min}$ for He and $14 \mathrm{~mL} / \mathrm{min}$ for $\mathrm{H}_{2}$, were allowed to flow through a saturator with liquid TCE at $25^{\circ} \mathrm{C}$ (TCE partial pressure of $92 \mathrm{mbar})$, resulting in a molar ratio of $\mathrm{H}_{2}: \mathrm{TCE}$ of 3:1. The exhaust of the reactor was connected to a HP5890 Series II gas chromatograph (Agilent, Vienna, Austria)equipped with an HP Poraplot Q 
column and a flame ionization detector (FID) for product analysis. Exhaust gases were fed via $\mathrm{NaOH}$ to scrub residual $\mathrm{HCl}$ from the gas phase $[125,126]$.

\section{Conclusions}

The effects of the nanoparticle shape, i.e., of the type of exposed surface facets, on selective hydrogenation of TCE to ethylene were examined for Pt and Pd NPs supported on $\mathrm{ZrO}_{2}$. Catalytic selectivity strongly depends on the type of metal and the exposed surface structures.

Cubic and cuboctahedral Pt NPs selectively produced ethane by full hydrogenation, even though they had different surface facets (c (100) and co (111) + (100)). Compared to the catalytic activity of c Pt NPs, the co Pt NPs lost catalytic activity more rapidly.

Spherical Pd NPs with stepped surfaces produced both ethylene and (somewhat more) ethane and showed higher catalytic activity at low reaction temperature, which decreased strongly due to poisoning by chlorine and carbonaceous species. In contrast to the s Pd NPs, polyhedral and multiply-twinned Pd NPs achieved higher selectivity towards ethylene and were more stable. The smooth Pd (111) surfaces seem to favor selectivity towards ethylene. It was confirmed that the hydrodechlorination reaction of TCE is structure sensitive and that catalytic selectivity can be altered by controlling the surface facets/structure. Designing the shape and thus surface properties of nanoparticles is a feasible route towards obtaining valuable catalytic products, but more studies are clearly needed.

Supplementary Materials: The following are available online at http://www.mdpi.com/2073-4344/10/11/1314/s1, Table S1: Results of ICP-OES., Figure S1: (a-d) TEM, (e) EDX, and (f) HR-TEM of ZrO2 supported cubic (c) Pt NPs (slightly rounded) after pretreatment and reaction., Figure S2: (a,b) STEM, (c) EDX, (d,e) TEM and (f) (HR-)TEM of $\mathrm{ZrO}_{2}$ supported cuboctahedral (co) Pt NPs after pretreatment and reaction., Figure S3: (a) STEM, (b) EDX, (c) HR-TEM and (d) FFT of $\mathrm{ZrO}_{2}$ supported spherical (s) Pd NPs after pretreatment and reaction., Figure S4: (a) STEM, (b) EDX, (c) HR-TEM and (d) FFT of $\mathrm{ZrO}_{2}$ supported mixed-shape (m) Pd NPs after pretreatment and reaction.

Author Contributions: Conceptualization, S.S., O.Y.S. and G.R.; methodology, O.Y.S., S.S. and G.R.; investigation, O.Y.S. and C.W.; resources, S.S. and G.R.; data curation, O.Y.S.; writing-original draft preparation, O.Y.S. and, G.R.; writing-review and editing, O.Y.S., S.S. and G.R.; and supervision, S.S., G.R. and O.Y.S. All authors have read and agreed to the published version of the manuscript.

Funding: This research was funded by Gumushane University, Scientific Research Projects Coordination Department, grant number 20.F5119.01.02 and 20.F5119.01.01. Instrumental access was supported by the Austrian Science Fund (FWF) via SFB FOXSI (F4502-N16) and I4434-N. Open Access Funding by the Austrian Science Fund (FWF).

Conflicts of Interest: The authors declare no conflict of interest. The funders had no role in the design of the study; in the collection, analyses, or interpretation of data; in the writing of the manuscript, or in the decision to publish the results.

\section{References}

1. Delpire, L.; Scarano, L. Environmental Protection Agency; 740-R1-4002; EPA: Washington, DC, USA, 2014; p. 212.

2. Weidlich, T.; Kamenická, B.; Melánová, K.; Čičmancová, V.; Komersova, A.; Čermák, J. Hydrodechlorination of Different Chloroaromatic Compounds at Room Temperature and Ambient Pressure-Differences in Reactivity of $\mathrm{Cu}$ - and Ni Based Al Alloys in an Alkaline Aqueous Solution. Catalysts 2020, 10, 994. [CrossRef]

3. Hahn, T.; Botzenhart, K.; Schweinsberg, F. 2-Toxic Effects of Solvent Exposure. Toxicokinet. Toxicodyn. Toxicol. 2014, $19,98$.

4. Schrick, B.; Blough, J.L.; Jones, A.D.; Mallouk, T.E. Hydrodechlorination of Trichloroethylene to Hydrocarbons Using Bimetallic Nickel-Iron Nanoparticles. Chem. Mater. 2002, 14, 5140-5147. [CrossRef]

5. Liu, Y.; Majetich, S.A.; Tilton, R.D.; Sholl, D.S.; Lowry, G.V. TCE Dechlorination Rates, Pathways, and Efficiency of Nanoscale Iron Particles with Different Properties. Environ. Sci. Technol. 2005, 39, 1338-1345. [CrossRef] [PubMed]

6. Mackenzie, K.; Frenzel, H.; Kopinke, F.-D. Hydrodehalogenation of Halogenated Hydrocarbons in Water with Pd Catalysts: Reaction Rates and Surface Competition. Appl. Catal. B Environ. 2006, 63, 161-167. [CrossRef] 
7. Lee, A.F.; Carr, P.A.; Wilson, K. Low temperature 111-trichloroethane dehydrochlorination over Pt catalysts: From model surfaces to the real world. Chem. Commun. 2004, 2774-2775. [CrossRef]

8. Lee, A.F.; Wilson, K. Sulfate-Enhanced Catalytic Destruction of 1,1,1-Trichlorethane over Pt(111). J. Phys. Chem. B 2006, 110, 907-913. [CrossRef]

9. Tee, Y.-H.; Bachas, L.; Bhattacharyya, D. Degradation of Trichloroethylene by Iron-Based Bimetallic Nanoparticles. J. Phys. Chem. C 2009, 113, 9454-9464. [CrossRef]

10. Fernandez-Ruiz, C.; Bedia, J.; Andreoli, S.; Eser, S.; Rodríguez, J.J.; Gómez-Sainero, L.M. Selectivity to Olefins in the Hydrodechlorination of Chloroform with Activated Carbon-Supported Palladium Catalysts. Ind. Eng. Chem. Res. 2019, 58, 20592-20600. [CrossRef]

11. Rabek, J.F.; Rinby, B.; Skowronski, T.A. Photothermal Dehydrochlorination of Poly(vinyl chloride). Macromolecules 1985, 18, 1810-1818. [CrossRef]

12. Hjertberg, T.; Martinsson, E.; Sorvik, E. Influence of the Dehydrochlorination Rate on the Degradation Mechanism of Poly(vinyl chloride). Macromolecules 1987, 21, 603-609. [CrossRef]

13. Starnes, W.H.; Ge, X. Mechanism of Autocatalysis in the Thermal Dehydrochlorination of Poly(vinyl chloride). Macromolecules 2004, 37, 352-359. [CrossRef]

14. Carter, W.P.L.; Luo, D.; Malkina, I.L. Investigation of the Atmospheric Ozone Formation Potential of Trichloroethylene; Halogenated Solvents Industry Alliance: Riverside, CA, USA, 1997; p. 71.

15. Andersin, J.; Parkkinen, P.; Honkala, K. Pd-catalyzed hydrodehalogenation of chlorinated olefins: Theoretical insights to the reaction mechanism. J. Catal. 2012, 290, 118-125. [CrossRef]

16. Jugnet, Y.; Bertolini, J.C.; Barbosa, L.A.M.M.; Sautet, P. Vibrational identification of the surface reaction intermediates for the dehalogenation of trichloroethene on PdCu(1 10$)$ alloy. Surf. Sci. 2002, 505, 153-162. [CrossRef]

17. Nutt, M.O.; Heck, K.N.; Alvarez, P.; Wong, M.S. Improved Pd-on-Au bimetallic nanoparticle catalysts for aqueous-phase trichloroethene hydrodechlorination. Appl. Catal. B Environ. 2006, 69, 115-125. [CrossRef]

18. Yu, H.; Kennedy, E.M.; Uddin, M.A.; Dlugogorski, B.Z. Catalytic hydrodehalogenation of halon 1211 $\left(\mathrm{CBrClF}_{2}\right)$ over $\gamma$-alumina-supported $\mathrm{Ni}, \mathrm{Pd}$ and Pt catalysts. Catal. Today 2004, 88, 183-194. [CrossRef]

19. Zhang, Z.C.; Beard, B.C. Genesis of durable catalyst for selective hydrodechlorination of $\mathrm{CCl}_{4}$ to $\mathrm{CHCl}_{3}$. Appl. Catal. A Gen. 1998, 174, 33-39. [CrossRef]

20. Barbosa, L.A.M.M.; Sautet, P. Trichloroethene Dechlorination Reactions on the PdCu (110) Alloy Surface: A Periodical Density Functional Theory Study of the Mechanism. J. Catal. 2002, 207, 127-138. [CrossRef]

21. Crampton, A.S.; Rotzer, M.D.; Landman, U.; Heiz, U. Can Support Acidity Predict Sub-Nanometer Catalyst Activity Trends? ACS Catal. 2017, 7, 6738-6744. [CrossRef]

22. Barrabes, N.; Cornado, D.; Föttinger, K.; Dafinov, A.; Llorca, J.; Medina, F.; Rupprechter, G. Hydrodechlorination of trichloroethylene on noble metal promoted $\mathrm{Cu}$-hydrotalcite-derived catalysts. J. Catal. 2009, 262, 239-246. [CrossRef]

23. Barrabés, N.; Föttinger, K.; Dafinov, A.; Medina, F.; Rupprechter, G.; Llorca, J.; Sueiras, J.E. Study of Pt-CeO 2 interaction and the effect in the selective hydrodechlorination of trichloroethylene. Appl. Catal. B Environ. 2010, 87, 84-91. [CrossRef]

24. Barrabes, N.; Föttinger, K.; Llorca, J.; Dafinov, A.; Medina, F.; Sa, J.; Hardacre, C.; Rupprechter, G. Pretreatment Effect on $\mathrm{Pt} / \mathrm{CeO}_{2}$ Catalyst in the Selective Hydrodechlorination of Trichloroethylene. J. Phys. Chem. C 2010, 114. [CrossRef]

25. Bonarowskaa, M.; Kaszkura, Z.; Łomota, D.; Rawskib, M.; Karpinski, Z. Effect of gold on catalytic behavior of palladium catalysts in hydrodechlorination of tetrachloromethane. Appl. Catal. B Environ. 2015, 162, 45-56. [CrossRef]

26. Flid, M.R.; Kartashov, L.M.; Treger, Y.A. Theoretical and Applied Aspects of Hydrodechlorination Processes-Catalysts and Technologies. Catalysts 2020, 10, 216. [CrossRef]

27. Rupprechter, G.; Somorjai, G.A. Palladium-catalyzed hydrogenation without hydrogen: The hydrodechlorination of chlorofluorocarbons with solid state hydrogen over the palladium (111) crystal surface and its implications. Catal. Lett. 1997, 17-20. [CrossRef]

28. Ribeiro, F.H.; Gerken, C.A.; Rupprechter, G.; Somorjai, G.A.; Kellner, C.S.; Coulston, G.W.; Manzer, L.E.; Abrams, L. Structure Insensitivity and Effect of Sulfur in the Reaction of Hydrodechlorination of 1,1-Dichlorotetrafluoroethane $\left(\mathrm{CF}_{3}-\mathrm{CFCl}_{2}\right)$ over Pd Catalysts. J. Catal. 1998, 176, 352-357. [CrossRef] 
29. Markova, V.K.; Philbin, J.P.; Zhao, W.; Genest, A.; Silvestre-Albero, J.; Rupprechter, G.; Rösch, N. Catalytic Transformations of 1-Butene over Palladium. A Combined Experimental and Theoretical Study. ACS Catal. 2018, 8, 5675-5685. [CrossRef]

30. Somorjai, G.A.; Contreras, A.M.; Montano, M.; Rioux, R.M. Clusters, surfaces, and catalysis. Proc. Natl. Acad. Sci. USA 2006, 103, 10577-10583. [CrossRef]

31. Carlsson, A.F.; Madix, R.J. The dynamics of ethylene adsorption on Pt (111) into di- $\sigma$ and $\pi$-bonded states. J. Chem. Phys. 2001, 115, 8074-8082. [CrossRef]

32. Díaz, E.; Faba, L.; Ordóñez, S. Effect of carbonaceous supports on the Pd-catalyzed aqueous-phase trichloroethylene hydrodechlorination. Appl. Catal. B Environ. 2011, 104, 415-417. [CrossRef]

33. Srebowata, A.; Kaminska, I.I.; Gizinski, D.; Wideł, D.; Oszczudłowski, J. Remarkable effect of soft-templating synthesis procedure on catalytic properties of mesoporous carbon supported $\mathrm{Ni}$ in hydrodechlorination of trichloroethylene in liquid phase. Catal. Today 2015, 251, 60-65. [CrossRef]

34. Fernandez-Ruiz, C.; Bedia, J.; Grau, J.M.; Romero, A.C.; Rodríguez, D.; Rodríguez, J.J.; Gómez-Sainero, L.M. Promoting Light Hydrocarbons Yield by Catalytic Hydrodechlorination of Residual Chloromethanes Using Palladium Supported on Zeolite Catalysts. Catalysts 2020, 10, 199. [CrossRef]

35. Tian, M.; Ma, M.; Xu, B.; Chen, C.; He, C.; Hao, Z.; Albilali, R. Catalytic removal of 1,2-dichloroethane over LaSrMnCoO $6 / \mathrm{H}-\mathrm{ZSM}-5$ composite: Insights into synergistic effect and pollutant-destruction mechanism. Catal. Sci. Technol. 2018, 8, 4503-4514. [CrossRef]

36. Wang, X.; Bokhoven, J.A.v.; Palagin, D. Atomically dispersed platinum on low index and stepped ceria surfaces: Phase diagrams and stability analysis. Phys. Chem. Chem. Phys. 2019, 22, 28-38. [CrossRef] [PubMed]

37. Tereshchenko, A.; Polyakov, V.; Guda, A.; Lastovina, T.; Pimonova, Y.; Bulgakov, A.; Tarasov, A.; Kustov, L.; Butova, V.; Trigub, A.; et al. Ultra-Small Pd Nanoparticles on Ceria as an Advanced Catalyst for CO Oxidation. Catalysts 2019, 9, 385. [CrossRef]

38. Fujiwara, K.; Okuyama, K.; Pratsinis, S.E. Metal-support interactions in catalysts for environmental remediation. Environ. Sci. Nano 2017, 4, 2076-2092. [CrossRef]

39. Wang, P.; Chu, Y.; Dong, F.; Shi, X.; Fu, C.; Li, X.; Li, J.; Lv, X.; Jiang, G. Strong pyrrolic-N-Pd interactions boost the electrocatalytic hydrodechlorination reaction on palladium nanoparticles. Nanoscale 2020, 12, 843-850. [CrossRef]

40. Suchorski, Y.; Kozlov, S.M.; Bespalov, I.; Datler, M.; Vogel, D.; Budinska, Z.; Neyman, K.M.; Rupprechter, G. The role of metal/oxide interfaces for long-range metal particle activation during CO oxidation. Nat. Mater. 2018. [CrossRef]

41. Cai, C.; Han, S.; Liu, W.; Sun, K.; Qiao, L.; Li, S.; Zu, X. Tuning catalytic performance by controlling reconstruction process in operando condition. Appl. Catal. B: Environ. 2020, 260, 118103.

42. Todoroki, N.; Tei, H.; Tsurumaki, H.; Miyakawa, T.; Inoue, T.; Wadayama, T. Surface Atomic Arrangement Dependence of Electrochemical $\mathrm{CO}_{2}$ Reduction on Gold: Online Electrochemical Mass Spectrometric Study on Low-Index Au(hkl) Surfaces. ACS Catal. 2019, 9, 1383-1388. [CrossRef]

43. Bernardo, C.G.P.M.; Gomes, J.A.N.F. The adsorption of ethylene on the (100) surfaces of platinum, palladium and nickel: A DFT study. J. Mol. Struct. 2001, 542, 263-271. [CrossRef]

44. Baeza, J.A.; Calvo, L.; Gilarranz, M.A.; Mohedano, A.F.; Casas, J.A.; Rodriguez, J.J. Catalytic behavior of size-controlled palladium nanoparticles in the hydrodechlorination of 4-chlorophenol in aqueous phase. J. Catal. 2012, 293, 85-93. [CrossRef]

45. Zhu, Z.; Barroo, C.d.; Lichtenstein, L.; Eren, B.; Wu, C.H.; Mao, B.; Bocarmé, T.V.d.; Liu, Z.; Kruse, N.; Salmeron, M.; et al. Influence of Step Geometry on the Reconstruction of Stepped Platinum Surfaces under Coadsorption of Ethylene and CO. J. Phys. Chem. Lett. 2014, 5, 2626-2631. [CrossRef] [PubMed]

46. Dong, C.; Lian, C.; Hu, S.; Deng, Z.; Gong, J.; Li, M.; Liu, H.; Xing, M.; ZhangZhang, J. Size-dependent activity and selectivity of carbon dioxide photocatalytic reduction over platinum nanoparticles. Nat. Commun. 2018, 9, 1252. [CrossRef] [PubMed]

47. Lykaki, M.; Stefa, S.; Carabineiro, S.A.C.; Pandis, P.K.; Stathopoulos, V.N.; Konsolakis, M. Facet-Dependent Reactivity of $\mathrm{Fe}_{2} \mathrm{O}_{3} / \mathrm{CeO}_{2}$ Nanocomposites: Effect of Ceria Morphology on CO Oxidation. Catalysts 2019, 9, 371. [CrossRef] 
48. Alayoglu, S.; Aliaga, C.; Sprung, C.; Somorjai, G.A. Size and Shape Dependence on Pt Nanoparticles for the Methylcyclopentane/Hydrogen Ring Opening/Ring Enlargement Reaction. Catal. Lett. 2011, 914-924. [CrossRef]

49. Li, Y.; Zhang, Y.; Jing, Q.; Lin, Y. The Influence of Pluronic F-127 Modification on Nano Zero-Valent Iron (NZVI): Sedimentation and Reactivity with 2,4-Dichlorophenol in Water Using Response Surface Methodology. Catalysts 2020, 10, 412. [CrossRef]

50. Aramendia, M.A.; Borau, V.; Garcia, I.M.; Jimenez, C.; Lafont, F.; Marinas, A.; Marinas, J.M.; Urbano, F.J. Influence of the Reaction Conditions and Catalytic Properties on the Liquid-Phase Hydrodechlorination of Chlorobenzene over Palladium-Supported Catalysts: Activity and Deactivation. J. Catal. 1999, 187, 392-399. [CrossRef]

51. Yuan, G.; Bai, J.; Gao, B.; Ren, L.; Mei, J.; Zhang, L. The effect of crystal facet (312) exposure intensity of $\mathrm{Ni}_{12} \mathrm{P}_{5}$ nanoparticle on its hydrodechlorination catalytic activity. Inorg. Chem. Commun. 2020, 111, 107595. [CrossRef]

52. Munoz, M.; Ponce, S.; Zhang, G.-R.; Etzold, B.J.M. Size-controlled PtNi nanoparticles as highly efficient catalyst for hydrodechlorination reactions. Appl. Catal. B Environ. 2016, 192, 1-7. [CrossRef]

53. Ruiza, C.F.; Bedia, J.; Bonal, P.; Rodriguez, J.J.; Gómez-Sainero, L.M. Chloroform conversion into ethane and propane by catalytic hydrodechlorination with $\mathrm{Pd}$ supported on activated carbons from lignin. Catal. Sci. Technol. 2018, 8, 3926-3935. [CrossRef]

54. Lan, X.; Xue, K.; Wang, T. Combined synergetic and steric effects for highly selective hydrogenation of unsaturated aldehyde. J. Catal. 2019, 372, 49-60. [CrossRef]

55. Rizo, R.; Roldan-Cuenya, B. Shape-Controlled Nanoparticles as Anodic Catalysts in Low-Temperature Fuel Cells. ACS Energy Lett. 2019, 4, 1484-1495. [CrossRef] [PubMed]

56. Arán-Ais, R.M.; Solla-Gullón, J.; Herrero, E.; Feliu, J.M. On the quality and stability of preferentially oriented (100) Pt nanoparticles: An electrochemical insight. J. Electroanal. Chem. 2018, 808, 433-438. [CrossRef]

57. Jang, S.; Moon, K.; Park, Y.; Park, S.; Park, K.H. Recent Studies on Multifunctional Electrocatalysts for Fuel Cell by Various Nanomaterials. Catalysts 2020, 10, 621. [CrossRef]

58. Crespo-Quesada, M.; Yarulin, A.; Jin, M.; Xia, Y.; Kiwi-Minsker, L. Structure Sensitivity of Alkynol Hydrogenation on Shape- and Size-Controlled Palladium Nanocrystals: Which Sites Are Most Active and Selective? J. Am. Chem. Soc. 2011, 133, 12787-12794. [CrossRef]

59. Eom, T.; Kim, W.J.; Lim, H.-K.; Han, M.H.; Han, K.H.; Lee, E.K.; Lebègue, S.; Hwang, Y.J.; Min, B.K.; Kim, H. Cluster Expansion Method for Simulating Realistic Size of Nanoparticle Catalysts with an Application in $\mathrm{CO}_{2}$ Electroreduction. J. Phys. Chem. C 2018, 122, 9245-9254. [CrossRef]

60. Liu, J.-X.; Filot, I.A.W.; Su, Y.; Zijlstra, B.; Hensen, E.J.M. Optimum Particle Size for Gold-Catalyzed CO Oxidation. Phys. Chem. C 2018, 122, 8327-8340. [CrossRef]

61. Mehmood, F.; Kara, A.; Rahman, T.S.; Henry, C.R. Comparative study of CO adsorption on flat, stepped, and kinked Au surfaces using density functional theory. Phys. Rev. B 2009, 79, 075422. [CrossRef]

62. Huang, L.; Zhang, X.; Wang, Q.; Han, Y.; Fang, Y.; Dong, S. Shape-Control of Pt-Ru Nanocrystals: Tuning Surface Structure for Enhanced Electrocatalytic Methanol Oxidation. J. Am. Chem. Soc. 2017, 140, 1142-1147. [CrossRef]

63. Bai, S.; Bu, L.; Shao, Q.; Zhu, X.; Huang, X. Multicomponent Pt-based Zigzag Nanowires as Selectivity Controllers for Selective Hydrogenation Reactions. J. Am. Chem. Soc. 2018, 140, 8384-8387. [CrossRef]

64. Delbecq, F.; Sautet, P. Competitive $\mathrm{C}=\mathrm{C}$ and $\mathrm{C}=\mathrm{O}$ Adsorption of $\alpha$ - $\beta$-Unsaturated Aldehydes on $\mathrm{Pt}$ and $\mathrm{Pd}$ Surfaces in Relation with the Selectivity of Hydrogenation Reactions: A Theoretical Approach. J. Catal. 1995, 152, 217-236. [CrossRef]

65. Wang, C.; Daimon, H.; Lee, Y.; Kim, J.; Sun, S. Synthesis of Monodisperse Pt Nanocubes and Their Enhanced Catalysis for Oxygen Reduction. J. Am. Chem. Soc. 2007, 129, 6974-6975. [CrossRef] [PubMed]

66. Michel, J.A.; Morris, W.H.; Lukehart, C.M. Synthesis of shaped Pt nanoparticles using common anions or small molecules as shapedirecting agents: Observation of a strong halide or pseudo-halide effect. J. Mater. Chem. A 2015, 3, 2012-2018. [CrossRef]

67. Long, N.V.; Chien, N.D.; Hayakawa, T.; Matsubara, T.; Ohtaki, M.; Nogami, M. Sharp cubic and octahedral morphologies of poly(vinylpyrrolidone)-stabilised platinum nanoparticles by polyol method in ethylene glycol: Their nucleation, growth and formation mechanisms. J. Exp. Nanosci. 2012, 7, 133-149. [CrossRef] 
68. Huang, J.; Buonsanti, R. Colloidal Nanocrystals as Heterogeneous Catalysts for Electrochemical $\mathrm{CO}_{2}$ Conversion. Chem. Mater. 2019, 31, 13-25. [CrossRef]

69. Mantella, V.; Castilla-Amoros, L.; Buonsanti, R. Shaping non-noble metal nanocrystals via colloidal chemistry. R. Soc. Chem. 2020, 1-10. [CrossRef]

70. Ren, J.; Tilley, R. Preparation, Self-Assembly, and Mechanistic Study of Highly Monodispersed Nanocubes. J. Am. Chem. Soc. 2007, 129, 3287-3291. [CrossRef]

71. Rupprechter, G.; Freund, H.-J. Adsorbate-induced restructuring and pressure-dependent adsorption on metal nanoparticles studied by electron microscopy and sum frequency generation spectroscopy. Top. Catal. 2001, 14, 1022-5528. [CrossRef]

72. Penner, S.; Rupprechter, G.; Sauer, H.; Su, D.S.; Tessadri, R.; Podloucky, R.; Schlögl, R.; Hayek, K. Pt/ceria thin film model catalysts after high temperature reduction: A (HR)TEM study. Vacuum 2003, 71, 71-76. [CrossRef]

73. Wang, D.; Penner, S.; Su, D.S.; Rupprechter, G.; Hayek, K.; Schlögl, R. SiO 2 -supported Pt particles studied by electron microscopy. Mater. Chem. Phys. 2003, 81, 341-344. [CrossRef]

74. Li, W.; Sun, Z.; Tian, D.; Nevirkovets, I.P.; Dou, S.-X. Platinum dendritic nanoparticles with magnetic behavior. J. Appl. Phys. 2014, 116, 033911. [CrossRef]

75. Lim, B.; Kobayashi, H.; Camargo, P.H.C.; Allard, L.F.; Liu, J.; Xia, Y. New insights into the growth mechanism and surface structure of palladium nanocrystals. Nano Res. 2010, 3, 180-188. [CrossRef]

76. Rupprechter, G.; Seeber, G.; Hayek, K.; Hofmeister, H. Epitaxial Noble Metal Particles upon Oxidation and Iduction. A Model System for Supported Metal Catalysts. Phys. Status Solidi (a) 1994, 146, 449-459. [CrossRef]

77. Cheong, S.; Watt, J.D.; Tilley, R.D. Shape control of platinum and palladium nanoparticles for catalysis. Nanoscale 2010, 2, 2045-2053. [CrossRef]

78. Anic, K.; Föttinger, K.; Wolfbeisser, A.; Bernardi, J.; Li, H.; Rameshan, C.; Rupprechter, G. Surface Spectroscopy on UHV-Grown and Technological Ni-ZrO 2 Reforming Catalysts: From UHV to Operando Conditions. Top. Catal. 2016, 59, 1614-1627. [CrossRef]

79. Long, N.V.; Ohtaki, M.; Nogami, M.; Hien, T.D. Effects of heat treatment and poly(vinylpyrrolidone) (PVP) polymer on electrocatalytic activity of polyhedral Pt nanoparticles towards their methanol oxidation. Colloid Polym. Sci. 2011, 289, 1373-1386. [CrossRef]

80. Nguyen, V.L.; Ohtaki, M.; Ngo, V.N.; Cao, M.-T.; Nogami, M. Structure and morphology of platinum nanoparticles with critical new issues of low- and high-index facets. Adv. Nat. Sci. Nanosci. Nanotechnol. 2012, 3, 025005. [CrossRef]

81. Leontyev, I.N.; Kuriganova, A.B.; Leontyev, N.G.; Hennet, L.; Rakhmatullin, A.; Smirnovad, N.V.; Dmitriev, V. Size dependence of the lattice parameters of carbon supported platinum nanoparticles: $\mathrm{X}$-ray diffraction analysis and theoretical considerations. RSC Adv. 2014, 4, 35959-35965. [CrossRef]

82. Londoño-Restrepo, S.M.; Jeronimo-Cruz, R.; Millán-Malo, B.M.; Rivera-Muñoz, E.M.; Rodriguez-García, M.E. Effect of the Nano Crystal Size on the X-ray Diffraction Patterns of Biogenic Hydroxyapatite from Human, Bovine, and Porcine Bones. Sci. Rep. 2019, 9, 5915. [CrossRef]

83. Muniz, F.T.L.; Mirand, M.A.R.; Santos, C.M.d.; Sasaki, J.M. The Scherrer equation and the dynamical theory of X-ray diffraction. Acta Crystallogr. A Found. Adv. 2016, 72, 385-390. [CrossRef]

84. Haghofer, A.; Sonström, P.; Fenske, D.; Föttinger, K.; Schwarz, S.; Bernardi, J.; Al-Shamery, K.; Bäumer, M.; Rupprechter, G. Colloidally Prepared Pt Nanowires versus Impregnated Pt Nanoparticles: Comparison of Adsorption and Reaction Properties. Langmuir 2010, 26, 16330-16338. [CrossRef] [PubMed]

85. Rupprechter, G.; Unterhalt, H.; Morkel, M.; Galletto, P.; Dellwig, T.; Freund, H.-J. Extending UHV studies to the mbar range: Vibrational SFG spectroscopy of high-pressure CO adsorption on $\mathrm{Pt}(111)$ and $\mathrm{Pd}(111)$. Vacuum 2003, 83-87. [CrossRef]

86. Rupprechter, G. Sum Frequency Generation and Polarization-Modulation Infrared Reflection Absorption Spectroscopy of Functioning Model Catalysts from Ultrahigh Vacuum to Ambient Pressure. Adv. Catal. 2007, 133-263. [CrossRef]

87. Rupprechter, G.; Unterhalt, H.; Morkel, M.; Galletto, P.; Hu, L.; Freund, H.-J. Sum frequency generation vibrational spectroscopy at solid-gas interfaces: $\mathrm{CO}$ adsorption on Pd model catalysts at ambient pressure. Surf. Sci. 2002, 502, 109-122. [CrossRef] 
88. Bertarione, S.; Scarano, D.; Zecchina, A.; Johanek, V.; Hoffmann, J.; Schauermann, S.; Frank, M.M.; Libuda, J.; Rupprechter, G.; Freund, H.-J. Surface Reactivity of Pd Nanoparticles Supported on Polycrystalline Substrates as Compared to Thin Film Model Catalysts: Infrared Study of CO Adsorption. J. Phys. Chem. B 2004, 108, 3603-3613. [CrossRef]

89. Zorn, K.; Giorgio, S.; Halwax, E.; Henry, C.R.; Grönbeck, H.; Rupprechter, G. CO Oxidation on Technological Pd- $\mathrm{Al}_{2} \mathrm{O}_{3}$ Catalysts: Oxidation State and Activity. J. Phys. Chem. C 2011, 115, 1103-1111. [CrossRef]

90. Lear, T.; Marshall, R.; Lopez-Sanchez, J.A.; Jackson, S.D.; Klapötke, T.M.; Bäumer, M.; Rupprechter, G.; Freund, H.-J.; Lennon, D. The application of infrared spectroscopy to probe the surface morphology of alumina-supported palladium catalysts. J. Chem. Phys. 2005, 123, 174706. [CrossRef]

91. Morkel, M.; Rupprechter, G.; Freund, H.-J. Finite size effects on supported Pd nanoparticles: Interaction of hydrogen with $\mathrm{CO}$ and $\mathrm{C}_{2} \mathrm{H}_{4}$. Surf. Sci. 2005, 588, L209-L219. [CrossRef]

92. Lear, T.; Marshall, R.; Gibson, E.K.; Schutt, T.; Klapötke, T.M.; Rupprechter, G.; Freund, H.-J.; Winfielda, J.M.; Lennon, D. A model high surface area alumina-supported palladium catalyst. Phys. Chem. Chem. Phys. 2005, 7, 565-567. [CrossRef]

93. Föttinger, K.; Emhofer, W.; Lennon, D.; Rupprechter, G. Adsorption and Reaction of $\mathrm{CO}$ on ( $\mathrm{Pd}-) \mathrm{Al}_{2} \mathrm{O}_{3}$ and (Pd-) $\mathrm{ZrO}_{2}$ : Vibrational Spectroscopy of Carbonate Formation. Top. Catal. 2017, 60, 1722-1734. [CrossRef]

94. Kaftan, A.; Kollhoff, F.; Nguyen, T.S.; Piccolo, L.; Laurin, M.; Libuda, J. Sensitivity of CO oxidation toward metal oxidation state in ceria-supported catalysts: An operando DRIFTS-MS study. Catal. Sci. Technol. 2016, 6, 818-828. [CrossRef]

95. Lundwall, M.J.; McClure, S.M.; Goodman, D.W. Probing Terrace and Step Sites on Pt Nanoparticles Using CO and Ethylene. J. Phys. Chem. C 2010, 114, 7904-7912. [CrossRef]

96. Gunasooriya, G.T.K.K.; Saeys, M. CO Adsorption Site Preference on Platinum: Charge Is the Essence. ACS Catal. 2018, 8, 3770-3774. [CrossRef]

97. Kitla, A.; Safonova, O.V.; Föttinger, K. Infrared Studies on Bimetallic Copper/Nickel Catalysts Supported on Zirconia and Ceria/Zirconia. Catal Lett. 2013, 143, 517-530. [CrossRef]

98. Stropp, A.; Termentzidis, K.; Paier, J.; Kresse, G.; Hafner, J. CO adsorption on metal surfaces: A hybrid functional study with plane-wave basis set. Phys. Rev. B 2007, 76. [CrossRef]

99. Soriaga, M.P.; Chen, X.; Li, D.; Stickney, J.L. Applications of physical methods to inorganic and bioinorganic chemistry. In High Resolution Electron Energy-Loss Spectroscopy; RA Scott, C.L., Ed.; John WILEY: Hoboken, NJ, USA, 2013.

100. Borodko, Y.; Lee, H.S.; Joo, S.H.; Zhang, Y.; Somorjai, G.A. Spectroscopic Study of the Thermal Degradation of PVP-Capped Rh and Pt Nanoparticles in $\mathrm{H}_{2}$ and $\mathrm{O}_{2}$ Environments. J. Phys. Chem. C 2010, 114, 1117-1126. [CrossRef]

101. Wang, Y.; Dong, X.; Yu, Y.; Zhang, M. Investigation on the conversion of ethylene to ethylidyne on Pt(100) and $\operatorname{Pd}(100)$ using density functional theory. Phys. Chem. Chem. Phys. 2016, 18, 26949-26955. [CrossRef]

102. Heard, C.J.; Siahrostami, S.; Grönbeck, H. Structural and Energetic Trends of Ethylene Hydrogenation over Transition Metal Surfaces. J. Phys. Chem. C 2016, 120, 995-1003. [CrossRef]

103. Xu, L.; Stangland, E.E.; Mavrikakis, M. Ethylene versus ethane: A DFT-based selectivity descriptor for efficient catalyst screening. J. Catal. 2018, 362, 18-24. [CrossRef]

104. Baxter, E.T.; Ha, M.A.; Alexandrova, A.N.; Anderson, S.L. Ethylene Dehydrogenation on Pt, 4,7,8 Clusters on $\mathrm{Al}_{2} \mathrm{O}_{3}$ : Strong Cluster Size Dependence Linked to Preferred Catalyst Morphologies. ACS Catal. 2017, 7, 3322-3335. [CrossRef]

105. Gorey, T.J.; Zandkarimi, B.; Li, G.; Baxter, E.T.; Alexandrova, A.N.; Anderson, S.L. Coking-Resistant Sub-Nano Dehydrogenation Catalysts: $\mathrm{Pt}_{n} \mathrm{Sn}_{\mathrm{x}} / \mathrm{SiO}_{2}(n=4,7)$. ACS Catal. 2020, 10, 4543-4558. [CrossRef]

106. Cassuto, A.; Hugenschmidt, M.B.; Parent, P.; Laffon, C.; Tourillon, H.G. A NEXAFS and UPS study of the adsorption of tetrachloroethylene, trichloroethylene, iso-, cisand trans-dichloroethylene on platinum surfaces at $95 \mathrm{~K}$ : Multilayers and monolayers. Surf. Sci. 1994, 310, 390-398. [CrossRef]

107. Moskaleva, L.V.; Chen, Z.-X.; Aleksandrov, H.A.; Mohammed, A.B.; Sun, Q.; Rosch, N. Ethylene Conversion to Ethylidyne over Pd(111): Revisiting the Mechanism with First-Principles Calculations. J. Phys. Chem. C 2009, 113, 2512-2520. [CrossRef]

108. Cremer, P.S.; Su, X.; Shen, Y.R.; Somorjai, G.A. Ethylene Hydrogenation on Pt (111) Monitored in Situ at High Pressures Using Sum Frequency Generation. J. Am. Chem. Soc. 1996, 118, 2942-2949. [CrossRef] 
109. Xu, L.; Bhandari, S.; Chen, I.; Glasgow, J.; Mavrikakis, M. Chloroform Hydrodechlorination on Palladium Surfaces: A Comparative DFT Study on Pd (111), Pd (100), and Pd (211). Top. Catal. 2020, 63, 762-776. [CrossRef]

110. Posada-Borbón, A.; Heard, C.J.; Grönbeck, H. Cluster Size Effects in Ethylene Hydrogenation over Palladium. J. Phys. Chem. C 2017, 121, 10870-10875. [CrossRef]

111. Roling, L.T.; Choksi, T.S.; Pedersen, F.A. A coordination-based model for transition metal alloy nanoparticles. Nanoscale 2019, 11, 4438-4452. [CrossRef]

112. Gao, F.; Goodman, D.W. Pd-Au bimetallic catalysts: Understanding alloy effects from planar models and (supported) nanoparticles. Chem. Soc. Rev. 2012, 41, 8009-8020. [CrossRef]

113. Pei, G.; Liu, X.; Wang, A.; Lee, A.F.; Isaacs, M.A.; Li, L.; Pan, X.; Yang, X.; Wang, X.; Tai, Z.; et al. Ag Alloyed Pd Single-Atom Catalysts for Efficient Selective Hydrogenation of Acetylene to Ethylene in Excess Ethylene. ACS Catal. 2015, 5, 3717-3725. [CrossRef]

114. Han, Y.; Sun, J.; Fu, H.; Qu, X.; Wan, H.; Xu, Z.; Zheng, S. Highly selective hydrodechlorination of 1,2-dichloroethane to ethylene over Ag-Pd/ZrO 2 catalysts with trace Pd. Appl. Catal. A Gen. 2016, 519, 1-6. [CrossRef]

115. Han, Y.; Gu, G.; Sun, J.; Wang, W.; Wan, H.; Xu, Z.; Zheng, S. Selective hydrodechlorination of 1, 2-dichloroethane to ethylene over $\mathrm{Pd}-\mathrm{Ag} / \mathrm{Al}_{2} \mathrm{O}_{3}$ catalysts prepared by surface reduction. Appl. Surf. Sci. 2015, 355, 183-190. [CrossRef]

116. Lee, A.F.; Carr, P.; Wilson, K. Direct Observation of Extremely Low Temperature Catalytic Dehydrochlorination of 1,1,1-Trichloroethane over Platinum. J. Phys. Chem. B 2004, 108, 14811-14814. [CrossRef]

117. Abdollahi, T.; Farmanzadeh, D. Selective hydrogenation of acetylene in the presence of ethylene on palladium nanocluster surfaces: A DFT study. Appl. Surf. Sci. 2018, 433, 513-529. [CrossRef]

118. Krooswyk, J.D.; Kruppe, C.M.; Trenary, M. In-situ spectroscopic monitoring of the ambient pressure hydrogenation of $\mathrm{C}_{2}$ to ethane on Pt (111). Surf. Sci. 2016, 652, 142-147. [CrossRef]

119. Sohn, H.; Celik, G.; Gunduz, S.; Dean, S.L.; Painting, E.; Edmiston, P.L.; Ozkan, U.S. Hydrodechlorination of trichloroethylene over Pd supported on swellable organically-modified silica (SOMS). Appl. Catal. B Environ. 2017, 203, 641-653. [CrossRef]

120. Zaera, F. New advances in the use of infrared absorption spectroscopy for the characterization of heterogeneous catalytic reactions. Chem. Soc. Rev. 2014, 43, 7624-7663. [CrossRef]

121. Beebe, T.P.; Yates, J.T. An in situ infrared spectroscopic investigation of the role of ethylidyne in the ethylene hydrogenation reaction on palladium/alumina. J. Am. Chem. Soc. 1986, 108, 663-671. [CrossRef]

122. Kaltchev, M.; Thompson, A.W.; Tysoe, W.T. Reflection-absorption infrared spectroscopy of ethylene on palladium (111) at high pressure. Surf. Sci. 1997, 391, 145-149. [CrossRef]

123. Usoltsev, O.A.; Pnevskaya, A.Y.; Kamyshova, E.G.; Tereshchenko, A.A.; Skorynina, A.A.; Zhang, W.; Yao, T.; Bugaev, A.L.; Soldatov, A.V. Dehydrogenation of Ethylene on Supported Palladium Nanoparticles: A Double View from Metal and Hydrocarbon Sides. Nanomaterials 2020, 10, 1643. [CrossRef]

124. Siddique, M.N.; Ahmed, A.; Tripathi, P. Electric transport and enhanced dielectric permittivity in pure and Al doped $\mathrm{NiO}$ nanostructures. J. Alloys Compd. 2018, 735, 516-529. [CrossRef]

125. Cristol, S.; Haller, L. Dehydrochlorination of 1-Trichloro-2-o-chlorophenyl-2-p-chlorophenylethane (o, p-DDT Isomer). J. Am. Chem. Soc. 1945, 67, 2222-2223. [CrossRef] [PubMed]

126. Cristol, S.J.; Bly, R.S., Jr. Mechanisms of Elimination Reactions. XXIII. Phenyllithium-induced Dehydrochlorination of the Isomeric Chlorodiphenylethene. J. Am. Chem. Soc. 1961, 83, 4027-4032. [CrossRef]

Publisher's Note: MDPI stays neutral with regard to jurisdictional claims in published maps and institutional affiliations.

(C) 2020 by the authors. Licensee MDPI, Basel, Switzerland. This article is an open access article distributed under the terms and conditions of the Creative Commons Attribution (CC BY) license (http://creativecommons.org/licenses/by/4.0/). 